\title{
More than an Antidote Against Amnesia... Some historiographical, theoretical, and methodological reflections on the history of education
}

\author{
Marc Depaepe
}

\begin{abstract}
As the title suggests, this article is a theoretical and methodological one, which looks mainly at the conceptualization of the history of education as a field of research. In doing so, it is also partly historiographical, as it deals with the history of pedagogical historiography, concentrating on the way in which the history of education was written and conceptualized in former times. The general idea is that the discipline has shifted over the years from an "over-educationalized" point of view towards a more historical one - a paradigm shift that has been labelled, moreover, as a "new cultural history of education". On the basis of earlier studies, some implications of this evolution are discussed further in this paper: the relevance of the discipline, the development of appropriate conceptual tools, and the use of sources for the history of education.
\end{abstract}

Keywords: pedagogical historiography, theory and methodology of history of education, relevance, conceptual tools, sources.

\section{INTRODUCTION}

Traditionally, the history of education has been conceived mainly as a history of pedagogical thought, as an adjunct to "pedagogy", delivering possible guidelines and solutions for educational practices as well as for the formation of an educational theory. During my career as a historian of education, however, I have become more and more convinced that pedagogical historiography will either be historical or not. Which immediately raises the issue of rel- evance. There is indeed a danger that educational historians, who traditionally work in pedagogical institutions - general, social, and cultural historians seem to pass up on the opportunity of contributing to the history of education except when it comes to writing histories of universities - are considered an unnecessary luxury as a result of the gradual historicization and the related marginalization of educational history. All the more so because their "discourse" is often diametrically opposed to what educators, teachers, educationalists, psychologists, and 
other pedagogical opinion-makers wish to hear. But I am not that concerned about the position of the history of education in the long term. It is my opinion that a critical understanding of history is still indispensable for catching the nature, identity, and intellectual foundations of all pedagogical activities.

After this, I want to demonstrate this claim by looking back historically at the quest for a "relevant" history of education. I am convinced that this enduring pursuit of relevance has led, ironically, to irrelevant educational research, including research into the history of education. In my opinion it is only when we, as historians, enter the domain of the history of science that we will be able to say something meaningful, based on our own competence, about possible aberrations of historical research in education. After all, the proof of the pudding is still in the eating.

\section{The Quest FOR RELEVANCE}

More than a decade ago, Jurgen Herbst, one of the former presidents of ISCHE, wanted to portray the State of the Art of the History of Education at the end of the Twentieth Century in North America, as well as in Europe. In his final considerations he said that historians of education have to "consider anew their presence as academics in programs of professional education". "Anew" implies, in this context, that there once existed a truly relevant history of education that was, indeed, integrated into teacher training programmes.
But what kind of history of education was that?

From the last quarter of the nineteenth century the success of the history of education in teacher training in most western countries depended on the theoretical relevance of the educational thought of the "great masters" (such as Montaigne, Comenius, Rousseau, and Pestalozzi), and, probably, even more on the prospect of inculcating a pedagogically correct attitude into future teachers. Gabriel Compayré, the standard-bearer of the French history of pedagogy, stated in 1884 that the various pedagogical systems of the great thinkers elevated the level of moral exhortation. We cannot imagine that Herbst simply wants to restore the moralizing of that oldfashioned, French republican history of education. Along with other leading scholars in the field, he believes that the golden era of American educational history is not to be situated in the nineteenth century but in the age of cultural revisionism of the 1960s and 1970s, during which the research agenda in the United States was strongly determined by the methodologically organized historiography of Bailyn, Cremin, and others. Indeed, we may well assume that a paradigm shift took place under the inspiration of cultural revisionism: the history of ideas was replaced by the postulate of the social history of education.

A closer look at this evolution, however, reveals a number of differentiations that can serve as an antidote to a monolithic and ahistorical conceptualization of the "history of the history of education", 
as Sol Cohen put it. Heinz-Elmar Tenorth and other German researchers observed as early as in the mid-1970s that the new paradigm of the "social" history of education could boast only a relative consensus and that was with regard to the methodological problem in a narrower sense: the general acceptance of social historical tools and research techniques, including quantitative methods. But this did not eliminate the fundamental diversity with regard to the methodological problem in a broader sense, namely the relationship between theory and history, not only in the field of education but also in that of the social sciences in general. There was a fairly high degree of dissension in the theoretical positioning of the discipline in West Germany. For the historian of education, of course, it made a big difference whether the role of his research was limited, as the godfather of empirical research, Wolfgang Brezinka, argued, to that of a pre-scientific "reservoir of hypotheses", or whether it was at the heart of the formation of educational theory, as in the historical socialization research of Ulrich Herrmann or the ideological-critical and neo-Marxist approaches in both West and East Germany.

These theoretical differences also had practical consequences in the international organization of the scientific community of historians of education. It may be true that, as a consequence of the impetus of presidents of ISCHE such as Brian Simon, Maurice De Vroede, and Jurgen Herbst himself, the "new" social history of education was inspirational in the founding and development of the International
Standing Conference for the History of Education, but this certainly did not hinder the flourishing of old-fashioned and, in my view, even dilettantish aspirations within the same organization concerning the "relevance" of the history of education to the solution of practical problems. One of the editors of a book that presented itself as the outcome of the meetings of the International Standing Working Group for the History of Education as a Field of Research and as a Teaching Subject within ISCHE simply echoed the assumptions of the old-fashioned nineteenth-century "historical pedagogy". According to Kadriya Salimova, for example, the history of education is the science dealing with the regularities (laws) of theoretical and practical development. Therefore, it must make further contributions to the solution of new tasks, set by our time and dictated by the demands of modernization and educational reforms oriented to the twenty-first century.

Without wanting to be exposed to the charge of methodological imperialism, I saw it as my duty in 1992, when president of ISCHE, to warn against such a purely utilitarian treatment of the educational heritage of the past. In my judgement, the explicit striving for ideological, theoretical, or practical advantage will inevitably lead to the mystification of history, to hagiographic, pedagogical hero worship and a partisan and presentistic reading of history - an opinion of which I became more and more convinced after the invitation, in October 1994, to participate in a Sino-Swiss Pestalozzi Project, 
as well as after a mission, in September 1995, to evaluate the existing research and teaching in the history of education at the universities of the province of Gauteng (the former Transvaal) in South Africa. In both cases my critical comments encountered simplistic reasoning about "lessons" of the past, for a large part hiding specific pedagogical and political interests in educational reform.

The nationally orchestrated attempts to popularize Pestalozzi's thought in China coincided with large-scale literacy campaigns in which the integration of manual labour and formal education was central. What makes Pestalozzi attractive in China is not so much his "profound historical significance" but his "great immediate significance", which is reflected in conclusions such as: "People of the contemporary era can absorb the quintessence [of Pestalozzi's educational thoughts] so as to direct and promote educational reform today"; "At present the kernel [of activity teaching] ... is still the basic ideas of Pestalozzi"; "With life-long devotion to education and indomitable willpower, Pestalozzi will always be a shining example for educators all over the world"; "Pestalozzi's thought on [labour and technical] education still has far-reaching significance for guiding educational practices nowadays"; "If one has Pestalozzi's universal love and readiness to save the world, he will be filled with "saint's zeal" and become ever successful", and so on. Ironically enough, analogous attempts to make good use of the heritage of the educational past can be found in some conservative (White) circles in South
Africa, where "historical pedagogy" is still used to legitimate traditional values (even unofficially under the flag of ISCHE!). On the basis of the so-called paedagogica perennis - a phenomenological construct about the essences of education derived from history - one can hear the plea for a "culturally-based" [that is: unicultural] education for the diverse ethnic and religious groups in the country. For Johannes Jordaan, for example, "education through the ages was always culturally interrelated. Culture, religion, vernacular and historicity were always inherently part of authentic education. Remember this when re-evaluating the integration of schools in South Africa [....] Cramming children from all these divergent cultural groups into the same classrooms negates the paedagogica perennis."

Although the political and ideological power implications of such reasoning still have to be brought to the surface by studying the concrete social and culturalhistorical context to which they relate, they nevertheless instinctively make me think back to how the Catholics fleshed out the subject of "the history of education" in pre-conciliar Flanders. After the First World War, the priest-educationalists De Hovre and Decoene made an attempt to underpin education from a Catholic point of view through the publication of the Vlaamsch Opvoedkundig Tijdschrift [Flemish Pedagogical Journal]. What they were ultimately aiming for was a conservative revolution, "a rebirth through rebaptisation in the eternal rejuvenating source of Catholic educational philosophy". For De Hovre, the Catholic philosophy of life 
was the "cornerstone" of all modern life theories, "the prototype, the Platonic idea, the essence of all real pedagogical thinking, the "paedagogia perennis", the foundation of real educational tradition, the mother tongue of educational wisdom, the herald of educational truth," against which all "idols" or "false sources" of modern educational theory would be judged. This combative position meant that historiography could not be neutral, and nor could educational theory. "All the theory from the modern understanding of historical data, has shown," again according to De Hovre, "that personal sympathy constitutes a primary condition for understanding a man, a work, or event," thereby indicating that the past had to be seen through Catholic eyes, in which the extent of admiration for the great educational heroes depended on the building blocks that they supplied to Catholic educational practice. Hence innovators (in this case "reform educationalists who wanted to start with the child") such as Ellen Key were labelled by Decoene and De Hovre as "big children" who surfaced in the century of the child "in order to put their great childishness in the place of age-old values".

That these assumptions have continued to resound in Catholic Flanders for a long time requires little debate. What is much more remarkable is perhaps their theoretical scientific analogy with the Marxist-Leninist principles of educational history and educational theory in the former Eastern Bloc, and more particularly in the so-called GDR, where a lot of consideration was given to the theoretical- methodological foundations. There too, the (dialectical) unity of the "logical" (theoretical) and "historical" formed the core of (historical) educational theory. Within the bounds of the Marxist-Leninist epistemology, the past appeared as the inevitable and necessary developmental process towards a socialist society. The history of human society was regarded as a succession of class conflicts. The different episodes of the class struggle were demarcated by a revolution, which in itself constituted the climax of the conflict. Once the class society had been transformed into a communist society as a result of the great revolution, the ordered nature of their blind determinism was disposed of. In this socialist form of society, people would get to know the forces that determine society. As a result they became the masters of history and they could apply this knowledge to the realization of the socialist message of salvation. This principle applied mutatis mutandis to Marxist-Leninist educational theory. Without a systematic exploration of the past, the progressive construction and planning of the future was impossible. Just like the past, present, and future, theory and practice in Marxism-Leninism were "dialectically" connected and thus inseparable from one another.

A number of functional consequences arose from these theoretical-methodological fundamentals for education in the history of education that were not only conceived as the centre of educational theory, but also as an essential component of general cultural history. First of all, the "pedagogic heritage" of the past had to be 
laid bare, as familiarity with the "progressive" legacy of earlier educationalists was very useful for historical, or shall we say socialist awareness in general, and that of teachers in particular. Moreover, the association with the "socialist" heritage could be placed in the struggle against "imperialist" and/or even "fascist" influences from abroad (in this case related to West Germany). Third. it was hoped that a problemoriented reading of the past would provide help in resolving contemporary problems, and finally, it also seemed to be an aid in making forecasts for future policy.

Such "strange uses of the past" were not just reserved for East Germany, but were also perceptible throughout the sphere of influence of the Soviet Union, with Hungary being no exception - I recall, here, as far as ISCHE is concerned, the position of Otto Vág, the third chairman of this international organization. The same "uses" of the past also bring me back to the issue of cultural revisionism in the United States. But the associated question of the functional value of the history of education is better viewed in the light of the long-term history of the subject. While the "history of education" from the end of the nineteenth century seemed to be a permanent feature on the curriculum of teacher training in the United States as well, mistrust grew after the First World War, because this part of the training did not seem to keep its pragmatic promises. In the 1920s and '30s this led to an extensive debate on the functional value of the history of education, which lost confidence as a subject in teacher training.
A survey in 1917 showed that only $12.7 \%$ of the teachers surveyed were convinced that the subject had been of any use to them. The answer of academics involved in the history of education related primarily to the content. They referred to the role, in this case the benefits, of public education in relation to the structure of American society. The school was the engine of democracy (read meritocracy), as Ellwood P. Cubberley called it. He set the tone with the construction of a linear-progressive account of the progress of the history of education. This narrative, which was not devoid of triumphalism, joined in with the general "Whiggish" (i.e. "teleological") interpretation of the target-oriented progress in (Western) civilization, from which nothing but good was expected.

However the "functional fallacy", as Frederic Lilge characterized the American expectations of the history of education in 1947, was far from finished. To begin with, the "success story" according to the Cubberley style further accentuated the professional discourse and ethos of the educationalists. In addition, the demand for a problem-oriented approach in social sciences from a social-reconstructive point of view resounded increasingly in the 1930 s. Only in this way could a "new" society, capable of managing contemporary problems, come into being. As a result, the history of education risked being reduced to a part of a "social foundations" course focused on current affairs. It was only after the Second World War that the way was cleared for a wider sociocultural perspective, in which educational history was no 
longer seen as the development of "formal pedagogy but rather as the entire process by which culture transmits itself across the generations". This "paradigm shift" was favoured by the so-called revisionism of the 1960 s, which, on a scientific-organizational level, was accentuated by the foundation of the History of Education Society in 1960 and the publication of History of Education Quarterly as of 1961. Incidentally, this (re?)development of the educational past by historians resulted in Edgar B. Wesley changing his thirty-six-year-old lament "Lo, the poor history of education" to the jubilant "Hail, the flourishing history of education"!

In practice, the revisionism of which Bernard Bailyn and Larry Cremin were the protagonists some fifty years ago meant a wider view of upbringing and education. In essence, as professional historians, the revisionists attacked the narrow-minded thesis of educationalists such as Cubberley about the "victory" of public education in American democracy. They charged it with being burdened with methodological sins such as presentism and evangelism. In the eyes of the revisionists, "The past was simply the present writ small". "But the supreme irony of the golden era was" - as Donato and Lazerson put it - "that radical revisionists [of the 1970s] gained attention by doing what previous generations of educational historians had done: They claimed an immediate connection to the present." Indeed, the radical revisionists, with, among others, Michael Katz as the pioneer, turned the old Cubberley thesis on its head. Far from having acted as an engine of democratization, the school lay at the basis of racism, class inequality, and unequal opportunities in the United States. As a kind of therapeutic assessment with an idealized past, educational history had to indicate the possibilities and priorities of future educational developments, within the critical and also generally neoMarxist perspective adopted by the radical revisionists. Hence post-revisionists such as Ravitch blamed the radicals for opening the door again for propaganda and the politicization of history with their "leftist" interpretation. However, they must not forget that their own research had been coloured by their assumptions about the present, even if they pleaded for a history of education in "its own right and in its own terms" - an observation that other researchers, in addition to Ravitch, also made. Today revisionism may be dead, as Herbst already noted at the end of the 1970s, but that does not automatically imply that the search for lessons from the history of education is over. On the contrary, Ravitch and others do not stop "learning from the Past". But their stories are much more sophisticated and, therefore, perhaps more veiled and dangerous than the utilitarian examples discussed above.

During the 1980s, another "new" history of education emerged in the United States and elsewhere, the so-called new "cultural" history of education, which was perhaps not so "new", since the "old" new history of education in Germany - to use the term of Jarausch - considered the social as well as the cultural dimensions of education from the outset as aspectual ex- 
pressions of a rich intellectual life. Moreover, this same qualification of the often inflated "paradigm shifts" applies, in my view, to the American development. Indeed, historians such as R. Freeman Butts may have believed, as Cubberley did, in the benefactions of American public education. Additionally, by the 1940s and ' 50 s they showed, at least embryonically, the way to a thoroughly socio-cultural analysis of education. Butts, for example, tried to find a balance between giving history a meaning for the present and upholding the integrity of the past. However that may be, this "new" cultural history of education - to which, among others, Sol Cohen contributed, although his concept of the "linguistic turn" recently came under fire from a methodological point of view - clearly gives evidence for presentism being more a condition of historical research than an abstract methodological sin. Writing and rewriting history ultimately belong to the present. In this respect postmodernism does not really force us to do anything new, "but it does oblige us to do it well and to be seen to doing it well", to quote Roy Lowe. And whether we label these activities "postmodern" or "high modern", as historical explanations, they will always need a kind of "hermeneutics", which, as Gadamer understood it, "is based on the historicity and linguisticity of experience, seeks the identification of meaning and the sense of memory which the narrator as mediator elaborates as a text, restoring and re-establishing the gaps in the story, even critically, so as to give the analysis the coherence it requires regarding the totality of the discourse and the context". According to Foucault, as human beings we are "condemned" to write and rewrite history from the point of view of the present. This does not imply legitimizing the systematic distortion of the past as a function of an ideologically fixed position. It does mean, however, that we, as professional historians, have to investigate how we ourselves rationalize and camouflage our own research strategies, research questions, and interpretative themes just as much as we have to unmask the hidden agendas and rhetoric of the educational discourse of previous generations.

To the degree to which we succeed in this endless task, the history of education will indeed acquire a post-modern added value: it deconstructs, demythologizes, and tarnishes the great, heroic, and often exaggerated stories of the past, not to ridicule our predecessors, their education, or their ideals but to demonstrate that they, too, were human beings, living in a concrete socio-historical context that it is difficult to abstract from. It qualifies the great emancipatory meta-narratives about education and shows that, at least from the nineteenth century onwards, education increasingly revealed a dynamic of its own that seems of itself not to have guaranteed the greater emancipation of the individual. The increase in educational opportunities did not necessarily provide increased opportunities for empowerment and autonomy but could also lead to subjection and dependence. Herbst is absolutely right in picking up Tenorth's demand to investigate this paradox within the "new" cultural 
history of education from the inside and not with conceptualizations and frameworks from the outside, i.e. mainstream history or sociology. And he is also right in describing with Tenorth these import theories as a most critical factor in the absence of knowledge about the history of everyday pedagogical practices in the classroom to the point where there is almost no place for "education" in the history of education, which can indeed help to explain the absence of historical awareness among teachers and educators. More recently, however, in line with the current outstanding Spanish research on school culture, some studies are dealing with the silences of classroom practices, but whether they will provide answers teachers and educators are willing to hear is very questionable.

Historical demystification about, for example, the practical impact of educational research or about the influence of educational innovation always seems to annoy and frustrate the believers. For this reason, in contrast with Herbst, I really do not believe that much in learning from the past or in the lessons that history will teach about school reform. Nor would I hold with the privatizing of the educational past by the individual or collective memory in order to put into action the lessons drawn from former experiences. To my mind, such added value of the history of education is situated on another, higher, more abstract, and de facto more personal level. The history of education shows in its research not only the relativity of the often overblown rhetoric with respect to the educational but also provides the impetus to deal with generally complex, sometimes paradoxical or ironic, and even problematic outcomes of the past. The problem is that it is difficult to strive intentionally for this advance in learning, the penalty being making history something other than history. For when history is placed in front of the cart of one or another ideological, political, or educational programme, it ceases to be history.

Certainly, policymakers will continue to use historical perspectives, but they do so primarily to advance their own agendas. Let us not be naive about this, as one of the books of the right-wing historian of education - or should I say conservative politician - Diane Ravitch about the historical damage caused by progressive education (with its "hedonistic, individualistic, anarchistic spirit") proves. The relevance of the history of education for the educators of the twenty-first century can, in my view, only be relevance of an intrinsic nature, i.e., one that is critical and inevitably uncomfortable, even for the "timetested truths" of the educational goals of "self-restraint", "self-discipline, and humility" that Ravitch wants to learn from the history of education. But such a history of education is, all in all, far from being a superfluous luxury for teachers. For what can the professional competence of practical educators consist of other than critical reflection on their activities past and present, especially since the ideological coverage of the traditional normative philosophies has fallen away? As Tom Popkewitz has pointed out, "concepts of educational research, like our commonsense ideas of 
teaching, cannot be treated as if they were natural but must be interrogated as historical monuments in social relations".

For sure, the history of education does not immediately yield the results that policymakers and politicians want to hear. Nor does it butter up rank-and-file teachers and others involved in education and upbringing. Because of this critical distance it erects a barrier against the hypertrophy of one-sided, utilitarian-designed educational research, which is based solely on empirico-analytical and statistically-quantifying thinking and generally demonstrates its merits through the highest possible quote indexes and impact factors. Historical contextualization is and will remain necessary, if for no other reason than to understand the effects triggered by these seemingly innocent mechanisms in putting into operation and measuring the scientific output of persons, institutions, and research domains. In other words, the traditional, more interpretational approaches to educational sciences, such as the historical, although also the philosophical (and perhaps even social) ones, may have become marginalized, but they are and remain indispensable in the forming of "critical" intellectuals.

The representation that is taking root in our current European society is largely one of economic cost-effectiveness and utility. The education sector is not escaping from the current washing away of this neoliberal ideology. Educational institutions are considered to be playing "the market" and "capturing" a specific "segment" or "niche" with their offering.
"Clientism" has not just been plucked out of the air. Quality controls are generally performed from the point of view of the satisfaction of the "user", rather than from being a critical reflection of what is to be achieved with education. Education is said to be a "business" that delivers knowledge and skills for the purpose of securing a place on the job market. Without risking a cultural-critical debate on the sense and nonsense of the requirements that are currently being placed on schools, it nevertheless has to be said that the dominance of such a representation strongly threatens to draw attention away from the cultural history of education. Investing in research into history is now difficult to reconcile with the priorities of management and efficiency thinking. Rather than willingly going along with the desiderata of financial market thinking, history enunciates an inconvenient discourse. The historical approach cultivates, as it were, the utility of the non-utilitarian. It sets itself up as a dam against the terror of the immediate practical benefit. From the critical distance of the cultural-historical view, research and education in history aims to go beyond the short-sightedness of modern times by placing its genesis into a lengthy story that will probably not be devoid of any paradoxes. Historical research, also in education, transcends the short-sightedness of our own time by making it clear that this prevailing drive for utility is only one element of the long-term process of modernization and thereby, at the very least, holds the door open for a critical corrective that could 
consist of the cultivation of the culture of the non-utilitarian. To believe that by ignoring history it will be possible to escape the social processes that it generates itself is, of course, a bitter illusion, even for those curriculum builders, educational innovators, policymakers, educational bureaucrats, and technocrats who in the meantime have turned their backs on history. To paraphrase Nietzsche, the task is and remains one of constantly reconciling oneself to the historicity of existence. And this brings me to my theoretical reflections on the history of education.

\section{The Quest for Appropriate Conceptual Tools}

By means of a historical story, a context in the past is created that the past itself did not know. Every historical researcher inevitably starts out from an artificially created collection of data that is grouped and regrouped into a text, and this text, in the view of Michel de Certeau, through its own structure and construction carries within it an unité de sens. Language is thus not an autonomous mirror or a photographic plate. It is, in fact, not a mirror at all; it represents the expression of ourselves and of what structures our thoughts. Only in historical discussion, in conversation with other researchers, does it articulate historical knowledge. The forming of historical knowledge is, therefore, not to be sought in the past itself but in the interpretative traditions of the historiographic operation. It assumes a distance in time, which makes possible the projection, the subjective historicity with which the researcher discovers and constructs the "different" in and the "being different" of the past. Such historical intervention, although it is never entirely "certain" of itself, is, however, not necessarily pure fiction. To the extent that the manufacturing of the past, in consultation with the usual practices of the present-day historiographic operation, is able to distinguish the false from the falsifiable, it can undoubtedly lay claim to being scientific. The exercise of history operates as critical hermeneutics. It arises from the break with the myth and rhetoric that previous historiographers have left behind and consequently results in something midway between fiction and science.

The history business, as a result of the so-called "linguistic turn", has gained more and more attention for the role of language, discursive practices, and the narrative structures in historical story. Sol Cohen, one of the leading historians of education in the United States, to whom we have already referred, argued, in this respect, as follows: "If the linguistic turn teaches us anything, it teaches us to read differently, we must begin to write differently. There is no single correct approach to reading a historical text; there are only ways of reading. Different reading strategies will constitute a historical text in different ways. The linguistic turn forces us to reconsider what kind of act the writing of history is, what our forms of emplotment permits or constraints, what kind of story we want to tell, and what kind of story we actually do tell." 
The grand theory of post-structuralists plays a decisive role in this new cultural history of education, of which Cohen is only one exponent. There is agreement with Foucault that it is not the unique human individual who is the author of the text and the intentions contained in it, but the exposition: the principle of the grouping of words, as a unit and origin of the meanings contained in it, and as a collecting-point for the relationship that exists between them. Instead of dealing with texts naively, the new cultural historians of education draw attention to textual silences and blind spots. Such signals betray, as it were, the unconscious aspect of a text. Texts do not refer un-problematically to what exists outside the text, but are the material externalization of structures and processes that have made the production possible. The new cultural historian of education therefore tries to understand how language and culture give intentionality to our deeds through their own logic. $\mathrm{He} / \mathrm{she}$ tries to grasp the sphere of discursive orders, symbolic practices, and media techniques that structure the involvement of the individual in society: "Our interest is in a historical imagination in the study of schooling that focuses on knowledge as a field of cultural practice and cultural production. It is to historicize what previously was subservient to a philosophical "unconsciousness," that is, the objects that stood as the monuments that projected its moral imperatives and salvation stories. This historicizing does not reject commitments but considers how commitments are interned and enclosed through the making of objects of interpretation, reflection, and possibility," as Tom Popkewitz wrote.

Focusing on the history of education, the linguistic turn therefore implies the re-orientation of a number of basic assumptions of modernism, which are related to the Enlightenment Project. First, the generalized process of thought was brought down. More specifically, a purely linear and teleological view of history was dismissed. In such a view, it is not only assumed that the "makeable" person and society can become "better" through development, but that this aim is at the same time revealed in the inherent dynamics of history. Second, the role of the subject as actor in history is rendered highly problematical. Rather than on the impulses to educational innovation and improvement that would have been based on the individual, the focus now is on the discursive space which structures the educational field. What is examined is how the discursive space comes about, how it develops, how it constructs subjects and social activities, and what forms of power and suppression are consequently produced and organized. In this way, the new cultural history aims to distance itself clearly from the paradigms that preceded it. Ultimately these are, according to Popkewitz, still excessively rooted in historicism. This historical tradition finds it difficult to live with the thought of an absent subject in history. The philosophy of the Enlightenment brought forth the idea of a self-aware actor, a creative and a priori subject that could be emancipated via universal knowledge and could consequently steer history in the di- 
rection of more humanity. Linked to the conceptions of liberalism and the modern state, this provided stories of progress on the blessings of upbringing and education and the good life of children, educators, and society.

In order to puncture the "false" historical awareness to which historicism has given rise, use can be made of the techniques of "deconstruction". This means that the "track" of the linguistic "drive" that such a historical awareness has brought forth must be exposed, or formulated differently, that the foundations of the linguistic code that structure and construct this exposition must be made visible. Following Foucault, it is assumed that the history of human knowledge and science comes down to the unravelling of the hidden regime and the general policy of "truth" that is active in it. On the basis of the awareness of this Sisyphean task, we have, in the context of educational historiography, repeatedly argued for a demythologizing perspective. Demythologizing is - in the sense of Rorty - a "cartographic" activity: mapping the field of discussion. In view of doing this, it is far from unnecessary to consider here what have been the dominant "paradigms" among historians of education.

Kuhn used the term "paradigm" in the sense of a model approach, a "disciplinary matrix" of coherent entities of laws, theories, applications, and instruments that belong to the consensus of a particular group of scientists. Paradigms are pivots around which the "revolutions" in the physical sciences turn. Kuhn emphasizes in particular in these revolutions the discontinuity with what preceded them. The transition from one paradigm to another, he argues, ushers in a state of crisis from which a new form of "normal" science can flourish. This transition in his view is not a cumulative process. It is more an "envelope" in which the points of departure for the redefinition of the specialist field become visible. With regard to writing the history of education, the argument of successive paradigms holds true to some extent, but in relation to the context of radical breaks in which that would happen we have considerable reservations. We conceive the development in the history of science of the discipline of the history of education far more as a continuum. This continuum presents itself as a richly chequered process of intersecting outcomes. The break lines, to which Kuhn has alluded in the context of his analysis of the natural sciences, are, with regard to educational historiography, principally breaks in "self-discourse" and not necessarily in the history of education research itself. The aim was to demonstrate via methodological, theoretical, or historiographic reflections on research how revolutionarily different the "new" approach was, so the category of "discontinuity" was obviously needed more for this than was "continuity".

As we have already seen, it is easy on the basis of the self-discourse in an international perspective to distinguish three to four phases in the post-war development of the history of education as a field of research. The preference for the new cultural history of education, which gained ground particularly during the course of 
the 1990s, was preceded by the (new) social history of education. This "paradigm shift" in the direction of a more socially or sociologically substantiated educational historiography is said to have taken place chiefly in the 1960s and 1970s. The new social history of education, according to the internal conceptualization in the field, replaced the "outdated" history of ideas of the great educational thinkers, which is said to have taken root particularly in the 1950s, partly in the context of teacher training. Following the nineteenth-century tradition, a "canonizing" encounter with one's own past, directed towards opening up what is educationally valuable in the heritage of the history of ideas, offered a good platform for legitimizing contemporary educational action. From the point of view of the history of the history of education, such an approach based on the history of ideas in turn contrasted with the antiquarian and chronologically constructed acts-and-facts history, which was often encountered in the context of institutional educational history. Such "school history", although it was not devoid of the modernist belief in progress, had, all things considered, turned out to be less functional than the history of ideas approach within the context of teacher training - as I have already demonstrated in the first section of this paper.

However, anyone who, on the basis of actual publications of educational history, wishes to investigate the specific evolutions and revolutions in the specialist field will soon come to the conclusion that the development of the research reality has been far more complex than these broad generalizations of the self-image of the discipline suggest. To begin with, the paradigms cited here intersect far more than is usually assumed. Social and cultural historiography on education is certainly not an invention of the late twentieth century. In the wake of German historicism, attention was already paid to the study of the organic growth that could be established in the relatively autonomous cultural field of education. This study naturally had a different appearance than the present-day profiles of social and cultural educational historiography, but this does not mean to deny that outpourings have continued to occur to the present to give the discipline a professional and educationally relevant appearance. To an extent, sedimentations of previous paradigmatic layers are still active. In addition, the heterogeneity of "new" impulses for both social and cultural historiography on education cannot be ignored. Far from having been a monolithic paradigm, the preference for social, let alone cultural educational, history was borne by a sturdy methodological debate on the role of history in theory-forming, in which diametrically opposed positions are often adopted: from empirical source description of social and cultural ties to education through the integration of sociological models and cultural theories anything but flat contours of schools and directions of research, which we cannot examine in detail here because of a lack of space.

What is needed today is, in our view, a mix of approaches, a mix of ways of seeing 
- a plurality of insights. As a result of being able to change perspective, we become better armed to deal with the heterogeneity of linguistic games and expositions from the educational past - as well as with the ensuing irony. Educational life, like political life, is not intrinsically ironic, but only becomes so through historical insight. This ironicalization takes place through the realization that the results of education and training can differ dramatically from what the educational activity had initially intended, just as the outcomes of politics can differ greatly from the objectives on which it is based. In this sense, we plead together with Carlos Barros neither for purely objectivistic historiography nor for a purely subjectivist approach: "We propose a Science with a human subject that discovers the past as people construct it" - which at the same time contains an awareness of one's own relativity (and the associated modesty). If we are not able to appreciate the relativity of the theories, concepts, and categories we use, we run the danger of not gaining anything and of losing everything... a piece of wisdom from Umberto Eco, which gives me the opportunity to say a final word about the sources and concepts we have to use.

\section{The Quest for Appropriate SourCe Material}

Traditionally, the historical craft has been characterized by tenacious source research, as described by the unfortunate Marc Bloch in his Apologie pour l"histoire ou Métier d"historien. The study of the past, as opposed to the study of the present, necessarily relies on "indirect" perception. Telling what has been (ton eonta legein, as Herodotus formulated it) cannot be done without the accounts of first-hand "witnesses". For Leopold von Ranke, who started teaching history in 1825 at Berlin University, the historian must work on the premise that historical factuality is pre-given. But facts by themselves say nothing. Hence, for Bloch "understanding" is the key word, the guide and the source of inspiration for research. But this understanding must, first of all, rely on facts, i.e. sources that have to be contextualized in time and space.

The first set of sources we have worked with - because of Professor De Vroede. to whom I owe a lot - was the "pedagogical press", i.e. periodicals. These sources constituted not only a mirror of the times, but they were also in most cases, as educational journals by educators and for educators, true guides to the theory as well as the practice of education. Little or nothing of what came to the surface in pedagogical life in Belgium escaped the attention of the journal editors and their colleagues of the time. In their many articles, they drew attention to and problematized the sore points and sensitivities that characterized everyday realities confronted by education providers, which enables these periodicals to be deemed a true goldmine for educational historiography; so to speak, the "mother of all pedagogical sources".

Indisputably, many of the texts published in the pedagogical press had a normative character; they were, ultimately, conceived from the supply side of formation and education and thus often expressed 
the intention of an educational objective or philosophy. Nevertheless, as we have indicated elsewhere, via an intelligent, generally indirect reading of the arguments (and expositions) used, it is possible to capture "normality" through this "normativity" of the source. Because these journals often had a very specific "mission" - some were explicitly founded to propagate a specific philosophy, ideology, and/or related vision of education - one can determine how that message developed at the level of "rhetoric" (if you will, the discourse of the "text") and how this was translated concretely into the everyday "reality" (of the practical-organizational "con"-text) and to what tensions, shifts, paradoxes, ironies, etc., all this gave rise. In this sense, the journals provide a relatively homogenous space - the articles came about under the editorship of likeminded people - and a solid basis for "diachronic" research (if one wants to do "developmental research"), which, moreover, can be done in large measure in a "depersonalized" manner. Indeed, the filter of the editing acted in most cases as an ideological buffer for what could/might be published and what could/might be turned down. Journals are thus not only a serial source but also a "closed" source that permits all sorts of quantitative (and/or quantifiable) operations to be conducted.

In tandem with the spirit of "cliometric" trends that were emerging in other countries, by the end of the 1970s, we were also interested at the time in working with educational statistics. During the first half of the 1990s, this resulted in the making available of Belgian educational statistics for primary education. These efforts yielded (some) international appreciation, and had an impact on a similar plan for secondary education. However, these factors did not represent the greatest benefit of the project. Unquestionably, this lay in the properly grounded source criticism that accompanied the publication of the figures. Obviously, the nineteenthcentury "objectification" of educational policy striven for by means of the publication of official figures did not escape the educational political agenda of the time. On the contrary, the generation of the numerical material, if you will, the "fabrication of the statistics" (to put it in the terms of Popkewitz and Lindblad), constituted an element of the policy strategy designed to promote the political objectives of the time. Therefore, we contextualized and read this policy-coloured governmental source as such. Staff (teachers as well as inspectors), urged by the administration to cooperate, did not always provide correct and accurate information. In addition to factors affecting accuracy, such as "routine", "incomprehension", and "fantasy", self-interest among the school personnel was naturally also operative.

Self-evidently, the same applies to the "oral history", with regard to which we are certainly not just starting out. For study concerning the social position of the teacher, we were able, for example, to make use of around a hundred interviews of oral witnesses. These interviews were conducted earlier within the framework of research into the development of professional teachers' organizations. Recently, 
we have dusted off the technique of oral history, e.g. within the framework of the study of the "progressive pedagogical heritage" in Flanders and of the structuring elements behind the experiences of the school past, in Belgium as well as in its former colony the Congo. Oral witness statements, just as much as statistics, are unable to give answers to all of our research questions. Although these sources often shed light on certain grey areas that are not illuminated by written sources, because of their a posteriori character and the accompanying discolouration, they necessarily have to be approached via a historical critique. Of course, such a critique can only emerge through a confrontation with other source material. In many cases, oral witness statements - as shown in our study of the progressive pedagogical heritage are, moreover, examples of autobiographical material and must be contextualized in relation to the life histories of the people involved. In short, it is again a mix of multifaceted source material that offers the best guarantee of adequate answers.

During the second half of the 1990s, we invested a great deal of time and energy in researching the school textbook - selfevidently a first-class source for historical research in education that, as such, had already been the object of analogous projects in other countries. France, Spain (followed by Latin America) and Germany, Canada, and others took the lead. However, our approach deviated in several ways from what was being propagated internationally. For example: we heavily criticized the supra-historical manner in which the ordering categories of bibliographical data were composed. Whoever wants to use textbooks for historical research in education has to have sufficient preliminary knowledge of the area. As we have repeatedly argued within the framework of the Internationale Gesellschaft für historische und systematische Schulbuchforschung in Ichenhausen, Germany, and of the IberoAmerican group PatreManes, such research involves much more than simply describing the content of textbooks themselves. It is important that one does not permit oneself to be held prisoner by a single source, however rich and important that source may be. Whoever wishes to draw out the pedagogical and didactic practices in the classroom via the textbook cannot do without the existing literature and the classic sources that have been amply discussed above. This certainly applies for one who wishes to place educational practice in its broader social context. Here, we can refer to our attempts to interpret the textbook in the colonial contexts of the Belgian Congo as an example. Here, statistics, governmental publications, having been printed with and without declarations of pedagogical intent, inspectors' reports, and chronicles dug up from archives of teaching congregations played a prominent role, as did ego documents - letters from missionaries, for example - as well as the oral testimonies of those who had to undergo colonial education.

All of this will not immediately strike the historical researcher as surprising. Education, as a social event, occurred not only at the classroom level, but was, as discussed 
with regard to statistics, very clearly embedded in the political-ideological framework of the nineteenth century. More striking, perhaps, is the observation that this conclusion also continues to apply for anyone who wishes to study educational practice both as a relative and as an autonomous phenomenon. From a content analysis of the textbooks themselves, one need not expect a faithful reconstruction of the pedagogical past in the classroom, let alone an impetus for the formation of any theory around it.

For the study of the everyday activities at the chalkface we do need other, complementary sources. Our studies that emerged at the end of the 1990s rested on many kinds of source material. Nevertheless, the periodicals again prevailed. By means of close reading we compared a number of journals that were selected to present a variety of conflicting viewpoints Catholic vs. non-Catholic, conservative vs. modern, and Dutch-language vs. Frenchlanguage. We studied journals from three key periods - the 1880s, the 1930s, and the 1960s. We discovered that despite the various societal contexts of these periods, there was a very strong line of continuity regarding formation and educational behaviour. By considering both "pedagogical" and "didactic" factors, we felt that we had contributed something of value with respect to the existing studies over what is called the "grammar of schooling". Previous studies had, admittedly, pointed to the tough historical structures of education but, in our opinion, had failed to appreciate sufficiently the pedagogical semantic within which this didactic grammar was immersed.

However, this pronounced preference for the pedagogical periodicals as opposed to the latest turns, such as the interest in the visual, was not appreciated everywhere. In this regard, we were even accused of "iconophobia". Had we been too traditional in our selection of sources and failed to appreciate a number of "modes" or "trends", or even missed genuine paradigms? All in all, the iconophobic position ascribed to us has little to rest on. We have never stated that one cannot or must not use iconographic sources. Rather, we insist on the fact that faith in the omnipotence of one source sometimes leads to onesided, context-free interpretations. Attention to discursive analysis of visual sources, which certainly applies to photographs, is far more pressing than is the case with written sources. In photographic language, the singular, the concrete, the accidental, and the mise-en-scène are radicalized and rendered absolute by the medium. But these photographs and films can hardly be interpreted without paying attention to the supporting message. With regard to our research into the history of the classroom, we found caricatured images from novels, as well as documentary and advertising messages that were "taken from life". But it is self-evident that the advertising messages were clad "in their Sunday best", presenting a cleaned-up picture of reality. This should not prevent us from taking that medium seriously. It is not simply the message that must be problematized for historical research. By using a variety of 
sources, one is better able to distance oneself from the story of the original actor in order to interrogate the story under way and therefore change the actual story, the actual explanation, more substantially.

At the beginning of this century the materialities of schooling became a growing concern for researchers. Such concern was directed towards a mishmash of artefacts, remnants of a pedagogical past that often have symbolic significance: school desks, slates, slate-pencils, pens, inkpots, blackboards, blackboard erasers, wall charts, and so on. Since the 1970s and ' 80 s, many of these things have been collected, preserved, and exhibited in school museums, which sprang out of the ground like mushrooms in the last decade of the twentieth century. Amassing such collections is obviously important, as is the development of museum expertise with regard to this material. However, it is important that such enterprises do not result in nostalgic navel-gazing or a narcissistic longing for the "the good old days" (with "back then" generally coinciding with the period of one's own childhood). We are more than a little concerned by the trend for generating income from the interest of older people who can enjoy themselves by "returning" to "the school of yesteryear". In our opinion, museums should definitely select their content with reference to scholarly research.

But historical research is, of course, more than a search for the ultimate source. To my mind, a new approach to educational historiography can never come from the sources themselves: anyone who remains imprisoned in his/her sources necessarily produces very descriptive work whose explanations are simply derived from the sources. And this is certainly not what contemporary pedagogical historiography needs, as I have tried to demonstrate in this paper, which is, in fact, a compilation of three earlier publications from the first decade of the twentieth century (see references).

\section{ReFERENCES}

Depaepe, M. (2001). A professionally relevant history of education for teachers: does it exist? Reply to Herbst's the State of the Art Article. Paedagogica Historica, 37, 631-640.

Depaepe, M. (2008). Dealing with Paradoxes of Educationalization. Beyond the Limits of "New" Cultural History of Education. Revista Educação \& Cidadania, 7(2), 11-31.

Depaepe, M., \& Simon, F. (2009). Sources in the Making of Histories of Education: proofs, arguments, and other reasonings from the historian's workplace. In P. Smeyers \& M. Depaepe (Eds.), Educational Research: Proofs, Arguments, and Other Reasonings (pp. 23-39). Dordrecht: Springer.

\section{FurThER REFERENCES}

Bauman, Z. (2000). Liquid modernity. Cambridge: Polity Press.

Catteeuw, K., Dams, K., Depaepe, M., \& Simon, F. (2005). Filming the black box: Primary schools on film in Belgium: A first assessment on unused sources. In U. Mietzner, K. Myers, \& N. Peim (Eds.), Visual history. Images of education (pp. 203-231). Oxford: Peter Lang. 
Compère, M.-M. (1997). Histoire du temps scolaire en Europe. Paris: INRP \& Economica.

Cuban, L. (19932). How teachers taught: constancy and change in American classrooms, 18801990. New York: Columbia University, Teachers College.

Cucuzza, H. R. (2007). La doctrina, la liturgia y los ejercicios espirituales. Los cuadernos escolares en la religiosidad patriótica laica. Paper presented at the International Symposium: Quaderni di scuola. Una fonte complessa per la storia delle culture scolastiche e dei costumi educativi tra Ottocento e Novecento. Macerata.

Dams, K., Depaepe, M., \& Simon, F. (2001). By indirections finding directions out: Classroom history, sources and objectives. In W. Jamrozek \& D. Zoladz-Strzelczyk (Eds.), W dialogu przesloscia. Ksiega poswiecona Profesorowi Janowi Hellwigowi [Dialogue with the Past. To Professor Jan Hellwig in Memoriam] (pp. 57-92). Poznan: Adam Mickiewicz University Press.

De Coninck-Smith, N. (2005). The panopticum of childhood: Harold E. Jones' Child Study Center, Berkeley, California, 1946-1960. Paedagogica Historica, 41, 495-506.

Dekker, J. J. H. (2001). The will to change the child. Re-education homes for children at risk in nineteenth century Western Europe. Frankfurt am Main: Peter Lang.

Depaepe, M. (1998). Educationalisation: a key concept in understanding the basic processes in the history of Western education. History of Education Review, 27(2), 16-28.

Depaepe, M. (2001). A professionally relevant history of education for teachers: Does it exist? Reply to Herbst's the State of the Art Article. Paedagogica Historica, 37, 631-640.

Depaepe, M. (2004). How should history of education be written? Some reflections about the nature of the discipline from the perspective of the reception of our work. Studies in Philosophy and Education, 13(5), 333-345.

Depaepe, M. (2006). Dealing with the historical paradoxes of a globalised educationalization - a way to write the "New" Cultural History of Education? In M. Cintje-Van Enckevort, M. George, \& S. S. Scatolini Apóstolo (Eds.), Proceedings from University of St. Martin - Educational Conference: Rethinking education in the Caribbean: Yesterday, today, and tomorrow. A local imperative in a global context. Papers on education and/or the Caribbean (Vols. 1-2). Philipsburg (St. Martin): University of St. Martin.

Depaepe, M., et al. (2000). Order in progress. Everyday education practice in primary schools Belgium, 1880-1970. Louvain: Leuven University Press.

Depaepe, M., \& Simon, F. (2002). Schulbücher als Quellen einer dritten Dimension in der Realitäts- und Mentalitätsgeschichte von Erziehung und Unterricht. Über neue Konzeptionen in der historisch-pädagogischen Schulbuchforschung. Zeitschrift für pädagogische Historiographie, 8(1), 7-15.

Depaepe, M., Simon, F., Surmont, M., \& Van Gorp, A. (2007). Menschen in Welten. Ordnungsstrukturen des Pädagogischen auf dem Weg zwischen Haus und Schule. Zeitschrift für Pädagogik, 52, 96-109.

Depaepe, M., Simon, F., \& Van Gorp, A. (2003). The canonization of Ovide Decroly as a "saint" of the New Education. History of Education Quarterly, 43(2), 224-249. 
Eggermont, B. (2001). The choreography of schooling as site of struggle: Belgian Primary Schools, 1880-1940. History of Education, 30, 129-140.

Escolano Benito, A. (Ed.). (2007). La cultura material de la escuela. En el centenario de la Junta para la Ampliación de Estudios, 1907-2007. Berlanga de Duero: Soria, CEINCE.

Fend, H. (2007). Die Grammatik des Bildungswesens und die "Logik" des Lehrerhandelns. In R. Casale \& R. Hörlacher (Eds.), Bildung und Öffentlichkeit. Jürgen Oelkers zum 60. Geburtstag (pp. 247-261). Weinheim/Basel: Beltz.

Ferraz Lorenzo, M. (Ed.). (2005). Repensar la historia de la educación. Nuevos desafios, nuevas propuestas. Madrid: Biblioteca Nueva.

Giesecke, H. (1996). Das Ende der Erziehung. Neue Chancen für Familie und Schule. Stuttgart: Klett-Cotta.

Hamilton, D. (1989). Towards a theory of schooling. New York: Falmer Press.

Herman, F., Depaepe, M., Simon, F., \& Van Gorp, A. (2007a). Punishment as an educational technology - a form of pedagogical inertia in schools? In P. Smeyers \& M. Depaepe (Eds.), Educational research: Networks and technologies (pp. 203-219). Dordrecht: Springer.

Herman, F., Depaepe, M., Simon, F., Surmont, M., \& Van Gorp, A. (2007b). Remembering the schoolmaster's blood-red pen. The story of the exercise books and the story of 'the children of the time' (1950-1970). Paper presented at the International Symposium: Quaderni di scuola. Una fonte complessa per la storia delle culture scolastiche e dei costumi educativi tra Ottocento e Novecento, Macerata.

Herrmann, U. (1986). Die Pädagogisierung des Kinder- und Jugendlebens in Deutschland seit dem ausgehenden 18. Jahrhunderts. In J. Martin \& A. Nitschke (Eds.), Zur Sozialgeschichte der Kindheit (pp. 661-683). Freiburg i. B.: Alber.

Kirk, D. (1998). Schooling bodies: School practice and public discourse, 1880-1950. London/ Washington: Leicester University Press.

Lawn, M., \& Grosvenor, I. (Eds.). (2005). Materialities of schooling: Design, technology, objects, routines. Oxford: Symposium Books.

Matthes, E., \& Heinze, C. (Eds.). (2007). Elementarisierung im Schulbuch. Bad Heilbrunn: Julius Klinkhardt.

Perrenoud, P. (1994). Métier d'élève et sens du travail scolaire. Paris: ESF.

Popkewitz, T. (2004). The alchemy of the mathematics curriculum: Inscriptions and the fabrication of the child. American Educational Research Journal, 41(1), 3-34.

Priem, K. (2006). Strukturen - Begriffe - Akteure? Tendenzen der Historischen Bildungsforschung. Jahrbuch für Historische Bildungsforschung, 352-370.

Ribolits, E., \& Zuber, J. (Eds.). (2004). Pädagogisierung: Die Kunst, Menschen mittels Lernen immer dümmer zu machen! Innsbruck: Studienverlag.

Schelsky, H. (1961). Anpassung oder Widerstand? Soziologische Bedenken zur Schulreform. Heidelberg: Quelle \& Meyer. 
Smeyers, P., \& Depaepe, M. (Eds.). (2006). Educational research: Why 'what works' doesn't work. Dordrecht: Springer.

Tenorth, H. E. (1996). Lob des Handwerks. Kritik der Theorie - Zur Lage der pädagogischen Historiographie in Deutschland. Paedagogica Historica, 32, 343-361.

Tyack, D., \& Cuban, L. (1995). Tinkering toward utopia: A century of public school reform. Cambridge, MA: Harvard University Press.

Tyack, D., \& Tobin, W. (1994). The grammar of schooling: Why has it been so hard to change? American Education Research Journal, 21, 453-479.

Van Gorp, A., Depaepe, M., \& Simon, F. (2004). Backing the actor as agent in discipline formation: An example of the "Secondary Disciplinarisation" of the educational sciences, based on the networks of Ovide Decroly (1901-1931). Paedagogica Historica, 41(5-6), 591-616.

Viñao Frago, A. (1996). Espacio y tiempo. Educaci'on y historia. Morelia (Mexico): IMCED.

Viñao Frago, A. (2001). Do educational reforms fail? A historian's response. Encounters of Education, 2, 27-47.

Zierer, K. (2006). Was bedeutet "Schule als Lebensraum"? Sechs Thesen zu einem "pädagogischen Programm”. Pädagogische Rundschau, 60, 49-59.

Prof. Dr. Dr. h.c. Marc Depaepe

University of Leuven, Faculty of Psychology and Educational Sciences;

e-mail:marc.depaepe@kuleuven.be 